\author{
Hupavtseva Nataliia \\ PhD in Psychology, Associate Professor \\ of the Department of General Psychology and \\ Psychological diagnostics of Rivne \\ State University of the Humanities \\ ORCID iD: 0000-0002-8883-7686 \\ DOI https://doi.org/10.35619/prap_rv.vi13.141
}

\title{
PSYCHOLOGICAL FEATURES OF FACILITATIVE INTERACTION IN THE PROCESS OF ORGANIZING DIALOGUES AT THE LESSONS AT SECONDARY SCHOOL
}

\begin{abstract}
Facilitative interaction is characterized by specific psychological, integrative and linguistic features. It was shown that from the psychological point of view dialogization is the process of facilitative speech interaction, which involves the exchange of replicas that do not reach the scope of monologue statements. The term "dialogue" is understood as the process of dialogue, and its result-text, but the text will not always be dialogically in the content.

The author of the article said that the dialogue (from "dialogues", diagonal, logos) was a conversation between two or more people. Expressions are short, often they are fragmentary replicas. We showed the psychological features of dialogical communication.

Dialogue as a product of coordinated verbal speech activity of two (three or more) interlocutors, is a coherent text that has all the main characteristics of the unambiguous unity. The parameters of the oral dialogue can be included: referring to one or another sphere of oral communication; the nature of the subject (one topic, a system of themes, several different themes); $a$ number of creators of the text (dialogue, trilogy, poly-dialogue); functional style of speech (spoken, officially or business, etc.); degree of readiness of the subjects of speech act (presence of workpieces, thoughts and facts, degree of mastering the topic); linguistic characteristics (normative language, composition of the dictionary, intonational design); situationality (the degree of support of speaking on infant communication channels in the process of their speech contact and the reflection of this particular communication in the text); depth and detail of the communicative development of the topic (or topics) that are discussed during the speech contact.

In the article we proposed the psychological features of facilitative interaction. The following psychological aspects influence the content and the nature of facilitative interaction: 1) the process of perception of the interlocutor's speech and orientation in the situation; 2) the processes of formation of the content of the statement; 3) the processes of linguistic design of thoughts and perception (plus decoding) of replica of partner in communication.

Observations on dialogues in real conditions show that any comprehension of the statement becomes the result of direct contact between people, creating the word "organizing", which form a single temporary communication system.

The initial statement is largely conditioned by the person of the interlocutor (as a component of the situation of communication), his/her attitude to the interlocutor, the competence in solving the problems discussed, the language partnership of the partners, the nature of their acquaintance. The personality of the interlocutor affects the initiator of the dialogue, contributes to its modeling in the psycho-physiological sense, tune in to a certain emotional system, which gives rise to the "launch" of the content-intentional level. Beginning the dialogue, the first participant (S.1) evaluates the communicative possibilities of the partner, is guided in the environment and on this basis creates his speech generating program, activates his speech intentions and the topic. The second interlocutor (S.2), who perceived the speech, had analyzed it and replies in response, taking into account the personality of the initiator of the dialogue and the environment, his own intentions and motives.
\end{abstract}

Key words: dialogical unity, dialogues, dialogical communication, facilitative interaction, communication system, functional style of speech. 
Problem's statement. Facilitative interaction is characterized by specific psychological, integrative and linguistic features. They need to be considered for the development of an appropriate training system and specific methodological recommendations. Let's define the basic concepts of facilitative interaction. First of all, facilitative interaction is a united situational-thematic community and communicative motives of the combination of verbal statements consistently generated by two or more interlocutors in the direct act of communication. Facilitative interaction at secondary schools often takes a place in the process of organizing dialogues.

From the psychological point of view dialogization is the process of facilitative speech interaction, which involves the exchange of replicas that do not reach the scope of monologue statements. The term "dialogue" is understood as the process of dialogue, and its result-text, but the text will not always be dialogically in the content (Cartwight and Zander, 1968).

Analysis of recent researches and publications. The dialogue (from "dialogues", diagonal, logos) is a conversation between two or more people. Expressions are short, often they are fragmentary replicas.

Let's show the linguistic features of dialogical communication.

Dialogue as a product of coordinated verbal speech activity of two (three or more) interlocutors, is a coherent text that has all the main characteristics of the unambiguous unity. The parameters of the oral dialogue can be included: 1960);

- referring to one or another sphere of oral communication (Gardner, Jackson and Messick,

- the nature of the subject (one topic, a system of themes, several different themes) (Enkvist, 1990); 1969);

- a number of creators of the text (dialogue, trilogy, poly-dialogue) (Kelley and Thibout,

- functional style of speech (spoken, officially or business, etc.) (Habermas, 2000);

- degree of readiness of the subjects of speech act (presence of workpieces, thoughts and facts, degree of mastering the topic) (Donald, Chemelsky and Palmer, 1982; Mykhalchuk and Ivashkevych, 2015);

- linguistic characteristics (normative language, composition of the dictionary, intonational design) (Csikszentmihalyi, 1990);

- situationality (the degree of support of speaking on infant communication channels in the process of their speech contact and the reflection of this particular communication in the text) (Fessenden, 1955);

- depth and detail of the communicative development of the topic (or topics) that are discussed during the speech contact (Kelley, 1973).

The purpose of the research. In this article we've to analyze concept of dialogical unity, such kinds of dialogues which are facilitative by their nature. We also shall propose the psychological features of facilitative interaction.

Methods and methodical instrumentation of the research. The following methods were used to study the empirical results of the research: a descriptive method - in order to distinguish dialogical unities; the method of distributive analysis - for dividing such kinds of dialogues which are facilitative by their nature; the method of syntactic transformation - to identify the psychological features of facilitative interaction.

The results of the research and their discussion. The dialogical text consists of dialogical unity, representing autonomous pairs of replicas, within which there is particularly close content $-\mathrm{a}$ lingual connectivity.

Dialogical unities can be constant and mobile (those that go over one another).

For example:

I.

1. - Did you live here for a long time?

2. - Long ago.

3. - How many years? 


$$
\text { 4. - It's more than twenty. }
$$

II.

1. - I really like to read.

2. - What to read?

3. - I am attracted to science fiction.

4. - And detectives do you like?

5. - No, somehow not so much.

In dialogue 1 replicas 2-4 are constant dialogical unities. In Dialogue 2, which consists of 5 replicas, 2, 3, 4 replies of dialogical unities are mobile. A specific feature of dialogical speech as the most characteristic variety of oral speech is its ellipticity. It is characteristic of all language levels of dialogical speech: phonetic, lexical, grammatical.

The phonetic ellipses is a reduction of sounds; for example, an auxiliary verb in the English language, which, together with a part of one or another lexical element is one word. For example: do not>don't; does not>doesn't; shall not> shan't; I have $>$ I've; he had $>$ he'd; had not $>$ hadn't; can not $>$ can't. Such ellipses include speech formations of this type:

'course (of course), 'cause (because), I was(It was ), what d'ye want? (What do you want?), etc.

The lexical ellipses manifests itself in the reduction of forms of full-fledged words and abbreviations of phrases. For example: exam (examination); prof (professor); doc (doctor); fridge (refrigerator); phone (telephone); flue (influenza); all right (It's all right); see you later (I'll see you later).

The grammatical ellipses is observed in dialogical speech both morphologically and syntactically. Morphological ellipses is either the release of a semantic verb or an infinitive part, or the omission of an auxiliary verb in analytic forms (for example: done < have done, had done, is done; going < are going (where ye goung? = where are you going?); have a smoke? (Will you have a smoke?); why didn't you come? You promised to.

The syntactical ellipses is a phenomenon typical for dialogical speech of any language. It is caused by three main factors:

1) transmission of information of voice communication channels;

2) reliance on speech works (own or interlocutor) who spoke at the moment of conversation;

3) combination of the first and the second factors.

For example:

I. - Look, Dmytro. What an angry and venerable is this one (a mother with her son are in the zoo, they are standing before the cage of the predator).

II. - Where are you going?

- To the station.

- Why?

- The baggage arrived.

In dialogical speech it is possible for a long time to communicate, never using the full sentence, with some statements reach extreme conciseness. For example: I am a coffee; He is so, she is not. In certain positions, the use of the full sentence seems unusual. In terms of education, this indicates a low level of language proficiency.

Some elliptical expressions and speeches are widely used in the practice of dialogue, becoming essentially linguistic signs (Yes, No, of course; Good; Can; Yes; Of course; All right; Thanks, etc.).

Into the concept of syntactical ellipses there are included the exclusions of structural elements of the sentence: prepositions, conjunctions, main and secondary members of the sentence, the main and subordinate sentences.

For example: (It) must be great to have a sister. (There) Ought to be some milk in the cup. (Are you; is he) Reading! (I am) Gland (I) saw him. cliché.

Some of the elliptical structures are fixed by the communicative practice and used as a 
Thank you (<I thank you); see you later ( $<$ I hope I'll see you later); all right $(<$ It is nice to see you); glad to meet you ( $<$ I am glad to meet you).

Another specific feature of the dialogical language is the relative collapse of syntactic qualities. Simple oral dialogues are characterized by simple sentence structures that consist of a small number of words. In an unprepared language, a short, simple phrase becomes more successful. It is more maneuverable, does not overpower the short-term memory, allows the interlocutor to come up with thoughts in order to later express them beautifully.

The dialogue language has an appeal to the interlocutor. Therefore, it is widely used verb forms of the second person, the imperative structures (Go for bread, Do the window, In what class do you study? Please open the door; Will you go to the sea this summer?). Approximately 20\% of all registered by S. M. Glenn (1983, p. 72) "ready" sentences in modern English household dialogues are characterized by communicative orientation towards the second person, in such a way they are turned to the interlocutor.

Speaking about the features of dialogical speech, one can not but point out the inherent lack of self-image (Wear a coat, it hangs there. Now it was such a rain. Sashka bought collections of poems. How are they called?). In dialogical speech there are many unfinished sentences, often used double substitutes. The syntactical structure of expressions is simplified. The degree of nonnormativity dialogical unities is more higher when:

1) the situation of communication is more free (that is there are familiar relationships between the participants in the dialogue);

2) it is less educated interlocutor;

3 ) it is less familiar to him the topic of conversation;

4) the second person speaks the language worse then the first one.

Oral speech, and especially dialogical one, has its own normative criteria, due to the nature of communication (reliance on the situation, lack of preparedness of the linguistic act of communication): where is the book (which) I left here? And will we sit in the car (when) how many people (gathered)?

Dialogical unities have peculiar expressions (colloquiums) that penetrate even the officialbusiness and professional functional-style registers used in appropriate situations of communication.

To illustrate the features of dialogical unities as it was discussed above, the text of the phonogram of the conversation of pupils of the $5^{\text {th }}$ form from secondary school № 15 , t. Rivne, topic "My room".

S.1: Have you ever...you know...sort of...Mum's said to you, like, Could you help me clear up? So you say, Yes, O.K., and you put your brother's or sister's things away, and then they come up and they say, Where's so and so? (Yeah...Yes) But then you think to yourself, Well, it's annoying to have...to have...to leave somebody's coat or something in the middle of the room...

S.2: And when they do complain, you feel as if you haven't done your job, but then you say, Well, I did pack it away, didn't it?.. You know...

S.3: It's annoying as well...

S.4: I do the same... I mean if I find anything lying around... if it's no good I just throw it away...

S.1: It might mean a lot...

S.4: I think in my family... I think my mother is the most considerate... she'd ask rather than my father... my father wouldn't.

S.1: Well, I'm lucky... I've got a room of my own... so...(...)

Such kinds of dialogues are facilitative by their nature. Let's analyze the character of the speech material used in the dialogical speech on the basis of sentences that can be classified in terms of:

a) communicative purpose (narrative, questionable, inductive, occlusive);

b) syntactical complexity (simple, complicated, complex);

c) completeness or uncompleteness (common, unpopular, elliptic); 
d) the degree of clipping (that is, the formality of the form before the moment of speech reproduction).

In the speeches of initiative subject, a significant place is occupied by questioning sentences (up to $40-50 \%$ ), followed by narrative (37\%). The answers in the first place are narrative sentences (up to $60 \%$ ), in the second one - questionable (up to $20 \%$ ).

The basis of the language material of the facilitative dialogues is simple sentences (70\%), most of which are widespread. Complex sentences are used much less often than simple, and in general are reduced to the transmission of causal and conditional-time relationships (with subordinate sentences of conditions and time).

Dialogue speech is characterized by a high level of clipping. However, cliches should not be reduced to the use of clichés such as "Good evening", "On health", "I ask for forgiveness" or we are talking about the massive use in dialogical communication of so-called finished sign languages, in contrast to speech productions, which are constructed in this moment of speech. Planned language unit is any linguistic sign (word, combination, sentence), which is repeated in the speech of the native speakers unchanged and becomes an indicator of the defined content and at the same time the level of its solution.

To speech cliche it is possible to attribute various ready-made phrases regardless of the presence or absence of figurativeness, idiolithicity, stability, and also regardless of the definition or meaningless content. Using the proposed facilitative dialogues we'll analyze the texts of spoken genres, as well as spontaneous speech recording of speech carriers, and concluded that a high level of cliche of oral text is especially dialogue speech (81\% for dialogue speech and only $56 \%$ for monologue text).

In the plan of presenting cliche the dialogue has another feature: the ratio of clicking marks of the sentence level above the corresponding indicator for the signs of the phrase. This can be explained by the fact that, at the sentence level (especially elliptic), the phraseology or even individual words are often used in dialogical speech. However, clashed (ready) can be full of sentences. This is clearly illustrated by the authors of the rational language from the point of view of the benefits of oral speech. Example:

S.1: What did you think of the film (play/concert/party)?

S.2: I liked it. I thought it was great (good/delightful).

S.1: Yes, I liked it, too. Did you like the acting (set/food)?

S.2: Yes, I thought it was excellent, didn't you?

S.1: Not really. I thought it was disappointing (poor/dull).

S.2: It is a nice cinema (theatre/house), isn't it?

S.1: Do you think so? I don't like it very much (...).

In this dialogue there are sentences-cliches and as many variations as it is possible (each variation is achieved by simple substitution). This dialogue can be considered by composed of language cliche at sentence level.

The origin of the linguistic cliche as a stable linguistic sign is due to the need for the members of the linguistic group to express the same type or similar thoughts, which implies the organic connection of the cliche with the communicative linguistic situation and its repeatability, uniformity.

The cliches is classified as follows: cliché-sentence, cliche-phrase, cliché level of sounds. The first two levels are grouped according to the functional generalization of the linguistic contact (acquaintance, representation), using the language formulas of etiquette, in the expression of standardized emotions (surprise, compassion) for the communicative accompaniment of the narrative (beginning, ending the conversation). Cliches of the level of the sounds of the sentence are grouped together with the generalization of linguistic examples (J. A. Fodor, M. Garrett, T. G. Bever (1968); J. Lull (1995)).

In such a way we'll propose the psychological features of facilitative interaction. The following psychological aspects influence the content and the nature of facilitative interaction:

1) the process of perception of the interlocutor's speech and orientation in the situation;

2) the processes of formation of the content of the statement; 
3) the processes of linguistic design of thoughts and perception (plus decoding) of replica of partner in communication.

Observations on dialogues in real conditions show that any comprehension of the statement becomes the result of direct contact between people, creating the word "organizing", which form a single temporary communication system.

The initial statement is largely conditioned by the person of the interlocutor (as a component of the situation of communication), his/her attitude to the interlocutor, the competence in solving the problems discussed, the language partnership of the partners, the nature of their acquaintance. The personality of the interlocutor affects the initiator of the dialogue, contributes to its modeling in the psycho-physiological sense, tune in to a certain emotional system, which gives rise to the "launch" of the content-intentional level. Beginning the dialogue, the first participant (S.1) evaluates the communicative possibilities of the partner, is guided in the environment and on this basis creates his speech generating program, activates his speech intentions and the topic. The second interlocutor (S.2), who perceived the speech, had analyzed it and replies in response, taking into account the personality of the initiator of the dialogue and the environment, his own intentions and motives. Thus, in a dialogical sense, the psychological basis of the generation of statements in the interlocutors is uneven. The meaningful side of the statements in dialogical contact is formulated on the basis of the life experience of those who communicate and a variety of incentives. The partner of communication may need:

1) to inform the partner about communication;

2) to collect information from the partner;

3) to attract the attention of the partner to any object or event;

4) to report on their observations, impressions, conclusions;

5) to establish any fact concerning one of the interlocutors, or both of them or other persons;

6) to express the partner's positive (negative) emotions.

It should be noted that the components of the situation within which the dialogue is held are in constant motion, which entails a change of incentives during one act of dialogical communication. During the dialogical speech, each of the participants of the contact has to solve a number of tasks of a psychological nature, such as:

1) to remember all previous conversations with this partner in order to maximize the experience of communicating, not to repeat;

2) to remember all that the interlocutor said during this contact, and all that he/she himself/herself said; action;

3) to instantly evaluate all information received before the beginning of partner's speech

4) be able to "insert your word" in time (not to violate the rules of communication adopted at that time);

5) to be able to listen to the interlocutor;

6) to maintain a certain emotional tone;

7) to observe the correctness of the speech form in which the opinions are drawn up;

8) to "listen" partner's speech in order to control its normativity and, if it is necessary, to make appropriate changes in the already sounded phrase;

9) to be able to select information from the situation of communication, which was reported by paralinguistic means (gestures, facial expressions) used by the interlocutor in the process of communication.

The psychology of a dialogue is due to the frequent change in the roles of the speaker and the listener, using various means of speech and thought activity. Linguistic mechanisms automatically take into account both the communication situation and the partner's text. For example:

I. - Go! (Exclamation in trolley-bus waiting situations).

II. - Are there many people in summer?

III. - Very! 
In the first case we have a deal with the orientation in the situation; in the second one - the partner who speaks responds to the text that heats, reduces (elipses) his/her statement, speaking only by the most meaningful word. Mechanisms and rules of ellipses are the same for both Ukrainian and English, French and other languages. There is a possibility of transferring communication skills from the native language to the one being studied, which, to a certain degree, facilitates the mastery of English dialectical speech.

Let us show the integrative features of the dialogue. Phrase-books turn to dialoging in the following cases:

1. When one of them suffers from a lack of knowledge, the interlocutor is competent in the field and is able to fill the information gap.

2. When the disclosure of a plot (topic) can not be realized by one interlocutor in a view of partner's speech impairment, lack of knowledge or the need for phased review of the said information.

3. When the partners need a mutual exchange of thoughts, impressions and experiences.

4. When there is a need to coordinate a variety of approaches to solve a specific problem to eliminate differences and contradictions.

Realizing a dialogue, a dialogical speech as the alternation of small utterances borders, on the one hand, with the beginning (end) of the communicative contact, and on the other one it is with the monological inserts, with which it is combined with the original sentences.

Dialogical speech should be considered as a communicative act, where the role of the communicator and the listener takes place. However, in the physical stage the interlocutors do not exchange speeches as it is customary to think, but compare these statements. Dialogical speech is not always the peaceful co-operation of partners, which is observed, as a rule, in formal communication (student-examiner) not rarely (as, for example, in situations of non-formal communication), the dialogue becomes an act of competition between two parties - rivals, when one of the interlocutors tries to monopolize audio channel: he/she interrupts a partner, does not listen to him/her and does not agree with his/her replica - the reaction to his/her statements. For example:

S.1: I can not live as much ...

S.2: You need to learn to respect ...

S.1: What do they want from me?!

S.2: ... people. Do not scream at them.

S.1: No, it's not life! ..

S.2: ... do not bother. If so ...

S.1: Unbelief! (Energetically gestures, says something incomprehensible).

S.2: ... continue, tomorrow no one will say "Good afternoon".

Such a dialogue can be interpreted as two adjacent monologues that collide only at separate points.

Dialogue, as well as any communicative act, is carried out in a concrete situation of communication and becomes its product. Meanwhile, in the hierarchical structure of verbal communication, the communicative situation as its primary particle does not exist in isolation, but within the broad spheres (for example, in the socio-cultural, social-household), the same type of social and communicative roles differ. It is essential that the kind of communication is one or another speech situation - individual or group, official or informal communication, free conversation or business conversation.

Conclusions and perspectives of further researches. Communicative situations in different spheres and types of communication are far from the same in terms of their text productivity, the degree of influence on the choice of theme, the depth and nature of its disclosure. Yes, all situations in the social sphere are in principle monotonous. All situations in the sociocultural sphere are usually political, because in any communication of friends (conversation in a circle of tea, a meeting of group-mates), speech activity becomes an end in itself, a necessary raw material for maintaining a high level of communicative communication. Here we can speak only about a certain range of topics (corresponding to the interests of the interlocutors), the emergence of 
which can be predicted from one or another degree of the possibility of a communicative situation in the vocational field (field of study) provide a set of themes that differentiate depending on the position (occupation) communes, from relevant events, documents. However, in general, the thematic complex in this area will always be combined with labor (training) activities. The language here, as a rule, becomes a means of achieving the infant practical purpose - the organization of any case or event. By the nature of the topics in the professional field, the sphere of game or admiration is approaching the most.

The situation of communication should include four components: circumstances, relations between communicators, speech motive and the process of dialogue, that is, the interlocutors perceived by the partners to express themselves. Initiative (the first) replica is important for deploying a dialogue. It becomes the initial speech stimulus and the bearer of the topic. The partner's reaction should be thematically coherent, but it is difficult to predict exactly what he will say. The unpredictability increases between the first and second replicas. The first partner can be identified by the program, but it is usually not immediately clearly disclosed.

From the communicative-informational point of view the first replicas can be reduced to the following types of statements:

1. Formulas for social communication (greetings, expressions of gratitude, apologies, need, etc.).

2. Request for information (a question, asking for something to inform).

3. Expression of emotions.

4. Informing.

5. Order - request.

6. Commenting (statement) of the circumstances in which the interlocutors are located.

7. Expression of the actual nature.

A statement, which becomes a reaction to a replica in a dialogue, depends on its content, can consist of both one and a few sentences (fragmentary statement, monological unity), that is why a dialogue may include a monologue. The replica-reaction to the monolithic insertion refers to the content of the entire statement, and not only to the last (final) sentence. From this it follows that the monologue insertions in the dialogue do not violate the dialogic speech activities of the partners.

Learning such a language in a foreign language requires a special methodology. The theme of dialogical speech will also have a wide range of questions. They are: people (their actions, appearance, character, biography, a language), events (in the personal life of their partners of communication or in the public sphere), language (as an object of attention, needs, property). The factors that shape the topic of dialogue are the relationships between the partners of communication, the level of their communicative unity, external events, etc. About psychological content of all these method we'll tell in our articles in future our issues.

\section{REFERENCES}

Cartwight, D., \& Zander, A. (1968). Group dynamics. Research and theory. New-York: New American library.

Csikszentmihalyi, M. (1990). Flow: The Psychology of Optimal Experience. New-York: Reading (Mass.).

Donald, H., Chemelsky, B., \& Palmer M. (1982). Nursery rhymes and prose passages: Preschooler's liking and short-term retention of story events. Developmental Psychology, 18 (1), 49-56).

Enkvist, N. E. (1990). Literary Pragmatics: On the Interpretability of Texts in General, and Literary Texts in Particular. New-York, London: Longman.

Fessenden, S. A. (1955). Levels of Distening. Education, 75, 18-26.

Fodor, J. A., Garrett, M., \& Bever, T. G. (1968). Some syntactic determinants of sentential complexity. Perception and Psychophysics (pp. 36-48). Oxford: Oxford University Press.

Gardner, R. W., Jackson, D. N., \& Messick, S. (1960). Personality organization in cognitive controls and intellectual abilities. Psychological Issues, 2 (8). 
Glenn, S. M. (1983). Nursery rhymes and early language acquaintance by mentally handicapped children. Exceptional children, 51 (1), 72-74).

Habermas, J. (2000). Teoria dzialania komunikacyjnego (T. 1). Warszawa: Ksiazka i Wedza.

Kelley, H. H., \& Thibout, J. W. (1969). Group problem solving. The Handbook Social Psychology (Vol. 4, pp. 36-48). New-York: Reading (Mass.).

Kelley, H. H. (1973). The process of causal attribution. American Psychology, 28, 2.

Lull, J. (1995). Media Communication. Culture. A Global Approach. Cambridge: Polity Press.

Mykhalchuk, N. O., \& Ivashkevych, E. Z. (2015). Crosscultural communication as a way to develop intercultural competence. Актуальні проблеми філологіі та методики викладання гуманітарних дисииплін (с. 3-8). Рівне: РДГУ.

\title{
REFERENCES
}

Cartwight, D., \& Zander, A. (1968). Group dynamics. Research and theory. New-York: New American library. [in English].

Csikszentmihalyi, M. (1990). Flow: The Psychology of Optimal Experience. New-York: Reading (Mass.). [in English].

Donald, H., Chemelsky, B., \& Palmer M. (1982). Nursery rhymes and prose passages: Preschooler's liking and short-term retention of story events. Developmental Psychology, 18 (1), 49-56). [in English].

Enkvist, N. E. (1990). Literary Pragmatics: On the Interpretability of Texts in General, and Literary Texts in Particular. New-York, London: Longman. [in English].

Fessenden, S. A. (1955). Levels of Distening. Education, 75, 18-26.

Fodor, J. A., Garrett, M., \& Bever, T. G. (1968). Some syntactic determinants of sentential complexity. Perception and Psychophysics (pp. 36-48). Oxford: Oxford University Press. [in English].

Gardner, R. W., Jackson, D. N., \& Messick, S. (1960). Personality organization in cognitive controls and intellectual abilities. Psychological Issues, 2 (8). [in English].

Glenn, S. M. (1983). Nursery rhymes and early language acquaintance by mentally handicapped children. Exceptional children, 51 (1), 72-74.

Habermas, J. (2000). Teoria dzialania komunikacyjnego (T. 1). Warszawa: Ksiazka i Wedza. [in Polish].

Kelley, H. H., \& Thibout, J. W. (1969). Group problem solving. The Handbook Social Psychology (Vol. 4, pp. 36-48). New-York: Reading (Mass.). [in English].

Kelley, H. H. (1973). The process of causal attribution. American Psychology, 28, 2. [in English].

Lull, J. (1995). Media Communication. Culture. A Global Approach. Cambridge: Polity Press. [in English].

Mykhalchuk, N. O., \& Ivashkevych, E. Z. (2015). Crosscultural communication as a way to develop intercultural competence. Aktualni problemy filolohii ta metodyky vykladannia humanitarnykh dystsyplin (s. 3-8). Rivne: RDHU. [in English].

\section{ПСИХОЛОГІЧНІ ОСОБЛИВОСТІ ФАСИЛІТАТИВНОЇ ВЗАЕМОДЇ̈ В ПРОЦЕСІ ОРГАНІЗАЦІЇ ДІАЛОГІВ НА УРОКАХ В СЕРЕДНІЙ ШКОЛІ}

\author{
Наталія Хупавцева \\ кандидат психологічних наук, доцент, доцент \\ кафедри загальної психології та психодіагностики \\ Рівненського державного гуманітарного університету \\ ORCID iD: 0000-0002-8883-7686 \\ DOI https://doi.org/10.35619/prap_rv.vi13.141
}

\begin{abstract}
Анотація. Фасилітативна взаємодія характеризується специифічними психологічними, інтегративними та лінгвістичними особливостями. В статті було показано, щуо з психологічної точки зору діалогізація - чуе прочес фасилітативної
\end{abstract}


мовленнєвої взаємодії, який передбачає обмін репліками, які не виходять за межі монологічних висловлювань. Термін «діалог» розуміється як процес обміну репліками та його результат - текст, але текст не завжди є діалогічним за змістом.

Авторка статті зазначає, що діалог - ие розмова двох або більше людей. Висловлювання є, як правило, короткими, часто ие - досить фрагментарні репліки. Було висвітлено психологічні особливості діалогічного спілкування.

Діалог як продукт узгодженої мовленнєвої діяльності двох (трьох $і$ більше) співрозмовників є иілісним текстом, який має всі основні характеристики однозначної єдності. Параметри усного діалогу можуть включати: посилання на ту чи іншу сферу усного спілкування; характер теми (одна тема, система тем, кілька різних тем); кількість учасників розмови, які беруть участь у побудові тексту (діалог, трилогія, полідіалог); функиіональний стиль мовлення (розмовний, офіційний чи діловий тощо); ступінь готовності суб'єктів мовленнєвого акту до діалогічного спілкування (наявність думок та фактів, ступінь опанування теми); лінгвістичні характеристики (нормативна мова, склад словника, інтонаційне оформлення); ситуативність мовлення; глибина та деталізація комунікативного розвитку теми (або тем), які обговорюються під час мовленнєвого контакту.

У статті запропоновано психологічні особливості фасилітативної взаємодії. Зазначено, щзо на зміст та характер фасилітативної взаємодії впливають такі психологічні аспекти: 1) прочес сприйняття мови та орієнтації співрозмовника в ситуації спілкування; 2) проиеси формування змісту висловлювання; 3) проиеси оформлення думок і сприйняття (та, разом з цим, розшифровка) репліки партнера у спілкуванні.

Спостереження за діалогами в реальних умовах комунікачії свідчать про те, щзо будь-яке розуміння висловлювання постає результатом прямого контакту між людьми, створюючи мовленнєві моделі, які утворюють єдину изілісну систему спілкування.

Зазначено, щзо під час фасилітативної взаємодії початкове твердження великою мірою зумовлюється особистістю співрозмовника (як складової частини ситуаціі спілкування), його/ї̈ ставленням до співрозмовника, компетентністю у розв'язанні проблем, які обговорюються, партнерством партнерів, характером їх знайомства тощзо. Особистість співрозмовника великою мірою впливає на ініціатора діалогу, сприяє моделюванню останнього в психофізіологічному сенсі, орієнтуючись, при цььом, на певну емоційну систему, щзо породжуе «запуск» змістово-інтенційного рівня комунікації. Починаючи діалог, перший учасник (S.1) оцінюе комунікативні можливості партнера по спілкуванню, орієнтується в оточенні $i$, на циій основі, створює свою власну програму дій, щчо великою мірою генерує мовлення, активізує мовленнєві наміри партнера з цієї теми. Другий співрозмовник (S.2), який сприйняв цей процес комунікації, аналізує іï та відповідає, враховуючи особистість ініціатора діалогу та оточення, його власні наміри та мотиви.

Ключові слова: діалогічна єдність, діалоги, діалогічне спілкування, фасилітативна взаємодія, система спілкування, функціональний стиль мовлення. 